\title{
ECONOMIC ANALYSIS OF COCONUT-BASED MIXED FARMING SYSTEMS
}

\author{
BY
}

H. P. Maheswarappa, C. V. Sairam, R. Dhanapal, T. Vidhan Singh and M. R. Hegde ${ }^{1}$.

\begin{abstract}
Coconut-Based Mixed Farming System which evolved from the Central Plantation Crops Research Institute is one of the technologies recommended for sustainable coconut production. The economic analysis of this system for the period 1989-90 to 1997-98, realized a net return between Rs. 49,700 to Rs. 126,900. The Cash Flow Analysis preformed using a discount rate of $14 \%$ realized the Benefit-Cost Ratio (BCR) of 1.36, the Net Present Worth of the system was Rs.286,500, the Internal Rate of Return was $27.44 \%$, and, the Pay Back Period was five years.
\end{abstract}

\section{INTRODUCTION}

Coconut is a smallholder's crop in India and more than $90 \%$ of the five million coconut holdings in the country are less than one ha in size. These smallholding coconut farms, often do not provide adequate income to the dependent families (Das, 1991). They do not provide gainful employment opportunities for thc family labor throughout the year. However, there are possibilities for increasing the productivity and net returns from coconut stands by raising compatible subsidiary crops and integrating livestock (Gopalasundaram et al., 1993). Adoption of coconut based farming systems is one of the ways to augment the productivity by improving soil characters and coconut nutrition (Maheswarappa et al., 1998) as well as the income per unit area.

One such system was being maintained at the Central Plantation Crops Research Institute, Kasaragod. This paper aims to test the economic worthiness of investment in coconut based farming system model under optimum management conditions based on experimental data.

\section{MATERIALS AND METHODS}

The study was based on the field experiment entitled, "Coconut Based Mixed Farming Systems" in sandy loam soil at the Central Plantation Crops Research Institute, Kasaragod from 1988-89 to 1997-98 in an 18 year old coconut garden in which pepper was trained on the coconut trunk and banana all along the border. Following were the livestock enterprises included in the system:

\section{Dairy Unit}

Five to six Jersey and Holstein Friesian breed cows were maintained in the system.

\section{Poultry Unit}

100 numbers of layers and 100 numbers of broiler (for each batch) birds were maintained in the system. In a year six batches of broilers were reared. 100 numbers of quail birds were also maintained.

\section{Biogas unit}

Biogas unit of $3 \mathrm{~m}^{3}$ was installed for generating biogas. The cowdung slurry from the gas plant and cow shed wastes along with urine were recycled within the experimental area.

\footnotetext{
${ }^{1}$ Division of Crop Production, Central Plantation Crops Research Institute, Kasaragod, Kerala, India.
} 


\section{Rabbits}

10 female and 4 male Russian chinchilla breeds were maintained.

\section{Aquaculture $\left(625 \mathrm{~m}^{2}\right.$ surface area):}

About 4-6 cm long fingerlings of four selected species viz. Catla (Catla catla), Rohu (Sebeo rohita), Mrighal (Cirrhinus mrighala and Grass carp (Ctenopharngdodon idellus) were reared in the pond.

Input and output details were collected and the market prices prevailed during the corresponding years in northern Kerala were considered to workout the economics of the system. All the calculations were performed for one hectare. The fixed cost was reduced to an annuity using a discount rate of $14 \%$ considering the economic life span of the system as 10 years. Tabular analysis was performed to identify the individual share of factors of production in the total cost. Based on the total return and total cost, the net return was worked out for individual years. Cash flow analysis (Sairman et al., 1999) was performed, using a discount rate of $14 \%$ and the economic viability of the system was assessed through economic indicators viz., Benefit-Cost Ratio, Net Present Worth, Internal Rate of Return and the Pay Back Period.

\section{RESULTS AND DISCUSSIONS}

\section{Costs}

The details on the cost of mixed farming system over years is furnished in Table 1. It could be inferred from the table 1989-1990 to 1997-98, among the different factors of production, the share of cattle feed and hired labor together had accounted between $56.33 \%$ to $75.72 \%$ of the total cost (Fig. 1). In addition, the entire system is maintained by 365 mandays for one male and one female labor. This system is labor intensive and under the present socio-economic conditions of state like Kerala, in which hired labor is both scarce and costly, the economic viability of this system could be improved, only through active participation by the family labor. Hence, it could be inferred that this model is more suitable for medium or larger coconut holdings with more number of persons depending on agriculture.

It could be further observed from Table 1 that the cost of poultry feed which was Rs. 4,930 during 1989-90, had increased to Rs. 18,610 during 1997-98 (+277.5\%). The total cost of the system (including the annuity value) which was Rs. 134,800 during 1989-90, had increased to Rs. 167,000 during 1997-98 (+23.9\%).

\section{Returns}

The output data from the different components of the system is furnished in Table 2. From the table it was inferred that during the period 1989-90 to 1997-98, the total production of coconut had exhibited an increasing trend. The same in the case of milk was fluctuating since the number of milch cows had declined. This was mainly due to the reduction in the number of milch cows reared under this system, which declined to three from 1996-97 onwards. Pepper was removed from the system during 1993-94 since high mortality rate had occurred due to quick wilt disease. The yield performance of banana was not satisfactory till 1992-93; however, the same had significantly improved in later years. The yield performance of other livestock components like rabbitry, poultry, and fishery was optimum over the years. 
The details on the returns over years from the coconut based mixed farming system are given in Table 3. It could be inferred from the table that the returns from coconut and milk was maximum accounting for 50-70\% of the total (Fig. 2). The returns from coconut had increased from Rs. 50,361 during 1989-90 to Rs. 88,200 during 1997-98 (+ 75.1\%). The share of coconut in the gross returns was stable over years. However, inter year fluctuations was there due to price fluctuations for coconut. In case of milk, the total returns had decreased from Rs. 92,071 to Rs. 78,576 (-14.7\%) since the number of milch cows was reduced. The share of milk in the gross return exhibited a declining trend. The returns from broiler birds had exhibited an increasing trend, and the same, which was Rs. 10,600 during 1989-90, had increased to Rs. 70,800 during 1997-98 and its share in gross return had increased from $5.96 \%$ to $26.45 \%$. The share of fish in the gross cost also exhibited an increasing trend. One of the major advantages of this system is that it produces and recycles organic manures like farm yard manure, biogas slurry and poultry manure at regular intervals. This could meet about $75 \%$ of the organic requirement for coconut and other subsidiary crops and their value was worth about $1 \%$ to $2.62 \%$ of the gross return. The realized gross returns had increased from Rs. 184,500 during $1989-90$ to Rs. $293,900(+59.29 \%)$ and the net returns from Rs. 49,700 to Rs 126,900 $(+155.33 \%)$.

\section{Cash Flow Analysis}

To assess the economic viability of this coconut based mixed farming system model, the cash-flow analysis was performed to work out the Benefit-Cost Ratio, Net Present Worth, Internal Rate of Return and Pay Back Period using a discount rate of $14 \%$. The results are shown in Table 4. The Benefit-Cost Ratio (BCR), Net Present Worth were 1.36 and Rs. 276,520, respectively. This indicated that for every one Rupee of investment in this system, the additional returns was Rs.0.36 which confirmed that under well managed conditions, coconut based mixed farming system is economically viable. The NPW of about Rs. 286,520 further indicates that this system would be more profitable. The Internal Rate of Return was $27.44 \%$ indicating the economic worthiness of financing this system. The Pay Back Period of five years indicated that the total initial investment of 2.6 lakhs could be recovered in five years. These indicators confirmed the economic worthiness of investment in coconut- based mixed farming system.

This system is able to provide fodder grass for feeding the cows worth Rs. 4,800 to Rs. 6,400 per year and if value is not imputed to the cattle feed cost, the BCR could increase to 1.41 and the Net Present Worth to Rs. 315,400. However, there was change in the values of IRR and Pay Back Period.

\section{SUMMARY}

The economic analysis of coconut-based mixed farming system for the period 1989-90 to 1997-98 under optimum management conditions was performed using the experimental data. It was observed that the total cost of the system, which was Rs. 134,800 during 1989-90, has increased to Rs. 167,000 during 1997-98. During the same period, the gross returns had increased from Rs. 184,500 to Rs. 293,900 and the net returns from Rs. 49,800 to Rs. 126,900 . The cash flow analysis performed using a discount rate of 14\% realized the Benefit-Cost Ratio (BCR) of 1.36 and the Net Present Worth of the system Rs. 286,520. The Internal Rate of Return was $27.44 \%$ and the Pay Back Period was five years. These results clearly indicate the economic viability of the system in medium and larger coconut holdings under irrigated conditions. Future research and developmental efforts should be initiated to understand and improve the existing status of coconut based farming systems under different agro-climatic and socio-economic environment of all the coconut growing states. 


\section{REFERENCES}

DAS, P.K., 1991. Economic viability of coconut based farming systems in India. J. Plantn Crops 19(2): 191-201

GOPALASUNDARAM, P., THOMAS VARGHESE , P., HEGDE, M.R., NAIR, M.G.K and DAS, P.K. 1993. Experiences in coconut based farming systems in India. In: Advances in coconut research and development, (eds) M.K. Nair, H.H. Khan, P. Gopalasundaram and E.V.V. Bhaskara Rao, Oxford \& IBH Publishing Co. Pvt. Ltd., New Delhi, pp. 383-394

MAHESWARAPPA, H.P., HEGDE, M.R., DHANAPAL, R. and BIDDAPPA, C.C. 1998. Mixed farming in coconut garden: Its impact on soil physical, chemical properties, coconut nutrition and yield. J. Plantn. Crops 26 (2): 139-143

SAIRAM, C.V., GOPALASUNDARAM, P., SRINIVASA REDDY, D.V., SUBRAMANIAN, P., UMAMAHESWARI, L., and HEGDE, M.R. 1999. Cash flow analysis of coconut based high density multi-species cropping system - Case study- J. Plantn. Crops 27 (1): 39-44

\section{ACKNOWLEDGEMENT}

The authors express their sincere thanks to Dr. M. K. Nair, Director (Retd.), Dr. K.U.K. Nampoothiri, Director, CPCRI Kasaragod, Dr. C.C. Biddappa, Head Division of Crop Protection (Retd.), CPCRI Kasaragod, and to all the staff members related to the project on coconut-based mixed farming at Kasaragod for their help and encouragement to carry out this study.

Table 1. Details on the Cost of Coconut Based Mixed Farming Systems in (ha (1989-90 to 1997-98)

\begin{tabular}{|l|r|r|r|r|r|r|r|r|}
\hline \multicolumn{1}{|c|}{ YEAR } & $\begin{array}{c}\text { Labour } \\
\text { Feed }\end{array}$ & \multicolumn{1}{c}{$\begin{array}{c}\text { Cattle } \\
\text { Feed }\end{array}$} & $\begin{array}{c}\text { Poultry } \\
\text { Feed }\end{array}$ & $\begin{array}{r}\text { Vet. } \\
\text { Medicine }\end{array}$ & \multicolumn{1}{|c|}{$\begin{array}{c}\text { Broiler } \\
\text { Birds }\end{array}$} & $\begin{array}{c}\text { Paddy } \\
\text { Straw }\end{array}$ & \multicolumn{1}{|c|}{ Fert } & \multicolumn{1}{c|}{$\begin{array}{c}\text { Finge } \\
\text { rings }\end{array}$} \\
\hline $1989-90$ & 20,000 & 53,800 & 4,930 & 3,890 & - & 480 & 3,500 & - \\
$1990-91$ & 20,000 & 49,180 & 9,340 & 1,780 & - & 2,370 & 3,670 & - \\
$1991-92$ & 24,000 & 55,870 & 13,740 & $2,, 350$ & 3,900 & 2,640 & 3,800 & 1,150 \\
$1992-93$ & 26,000 & 50,160 & 16,630 & 2,650 & 3,900 & 3,620 & 6,080 & 1,150 \\
$1993-94$ & 26,000 & 68,680 & 16,690 & 4,930 & 1,000 & 2,500 & 6,130 & 1,200 \\
$1994-95$ & 30,000 & 64,540 & 17,640 & 3,440 & 1,000 & 2,230 & 6,200 & 1,200 \\
$1995-96$ & 30,000 & 63,080 & 34,240 & 2,610 & 3,000 & 5,500 & 6,300 & 1,250 \\
$1996-97$ & 34,000 & 57,620 & 40,580 & 1,970 & 8,360 & - & 7,000 & 1,250 \\
$1997-98$ & 40,000 & 40,190 & 18,610 & 1,880 & 5,220 & 3,000 & 7,200 & 1,300 \\
\hline
\end{tabular}

\begin{tabular}{|c|r|r|r|r|r|r|r|}
\hline YEAR & Fish Feed & $\begin{array}{c}\text { Fodder } \\
\text { Grasses }\end{array}$ & \multicolumn{1}{|c|}{ Irrigation } & $\begin{array}{c}\text { Miscellaneo } \\
\text { us }\end{array}$ & Total Cost & Annuity & Total* $^{*}$ \\
\hline $1989-90$ & - & 4,800 & 1,000 & 1,927 & 94,300 & 36,400 & 130,700 \\
$1990-91$ & - & 5,200 & 1,000 & 114 & 93,500 & 36,400 & 129,900 \\
$1991-92$ & 3,200 & 5,830 & 1,000 & 1,117 & 118,700 & 36,400 & 155,100 \\
$1992-93$ & 3,200 & 5,940 & 1,500 & 1,159 & 122,000 & 36,400 & 158,400 \\
$1993-94$ & 3,350 & 6,360 & 1,500 & 1,320 & 139,700 & 36,400 & 176,100 \\
$1994-95$ & 3,350 & 6360 & 1,500 & 1,333 & 138,800 & 36,400 & 175,200 \\
$1995-96$ & 3,400 & 6,360 & 2,000 & 1,514 & 159,300 & 36,400 & 195,700 \\
$1996-97$ & 3,500 & 6,360 & 2,000 & 1,573 & 164,300 & 36,400 & 200,700 \\
$1997-98$ & 3,500 & 6,360 & 2,000 & 1,229 & 130,600 & 36,400 & 167,000 \\
\hline
\end{tabular}

* Rounded total 
Table 2. Production of Different Components in Coconut Based Farming Systems

\begin{tabular}{|c|r|r|r|r|r|r|}
\hline Year & $\begin{array}{r}\text { Coconut } \\
\text { No.(1 ha) }\end{array}$ & Milk (itres) & Pepper kgs) & Banana kgs) & Quails (Nos.) & $\begin{array}{c}\text { Hen egg } \\
\text { (Nos.) }\end{array}$ \\
\hline $1989-90$ & 16,787 & 13,153 & 90 & 530 & 100 & 7,990 \\
$1990-91$ & 21,347 & 12,719 & 96 & 319 & 100 & 1,729 \\
$1991-92$ & 16,733 & 9,305 & 62 & 608 & 112 & 965 \\
$1992-93$ & 17,674 & 7,877 & 60 & 307 & 80 & 2,819 \\
$1993-94$ & 18,404 & 10,873 & - & 320 & 86 & 2,696 \\
$1994-95$ & 19,125 & 9,235 & - & 526 & 90 & 3,500 \\
$1995-96$ & 19,388 & 10,701 & - & 502 & 100 & 2,887 \\
$1996-97$ & 19,412 & 5,948 & - & 1,090 & 80 & 272 \\
$1997-98$ & 19,600 & 6,543 & - & 885 & 80 & - \\
\hline
\end{tabular}

\begin{tabular}{|c|c|c|r|r|r|r|}
\hline Year & $\begin{array}{c}\text { Quail egg } \\
\text { (Nos.) }\end{array}$ & Rabbits (kgs) & Fish (kgs) & $\begin{array}{c}\text { Green grass } \\
(\mathrm{kgs})\end{array}$ & $\begin{array}{c}\text { Poultry } \\
\text { manure (kgs) }\end{array}$ & FYM (tones) \\
\hline $1989-90$ & 3,768 & 87.5 & - & 4,800 & 2,000 & 15 \\
$1990-91$ & 3,948 & 45 & - & 5,200 & 2,500 & 16 \\
$1991-92$ & 3,359 & 24 & 400 & 5,830 & 2,000 & 15 \\
$1992-93$ & 4,084 & 28 & 400 & 5,940 & 2,500 & 16 \\
$1993-94$ & 2,515 & 20 & 380 & 6,360 & 3,000 & 16 \\
$1994-95$ & 1,100 & 10 & 400 & 6,360 & 3,000 & 16 \\
$1995-96$ & 1,018 & - & 390 & 6,360 & 2,000 & 15 \\
$1996-97$ & 2,077 & - & 380 & 6,360 & 2,000 & 14 \\
$1997-98$ & 2,096 & - & 380 & 6,360 & 2,500 & 13 \\
\hline
\end{tabular}

Table 3. Details on Returns from Coconut Based Mixed Farming Systems in Rs./ha (1989-90 to 1997-98)

\begin{tabular}{|c|r|r|r|r|r|r|r|r|}
\hline \multicolumn{1}{|c|}{ YEAR } & Coconut & \multicolumn{1}{c|}{ Milk } & \multicolumn{1}{c|}{ Pepper } & Banana & \multicolumn{1}{c|}{ Broiler } & Quail & Hen egg & Quail egg \\
\hline $1989-90$ & 50,361 & 92,071 & 3,150 & 1,250 & 10,600 & 1,500 & 11,985 & 1,884 \\
$1990-91$ & 64,041 & 89,033 & 3,360 & 981 & 7,975 & 1,500 & 2,594 & 1,974 \\
$1991-92$ & 50,199 & 74,440 & 2,790 & 1,500 & 18,240 & 2,240 & 1,448 & 1,680 \\
$1992-93$ & 61,859 & 63,016 & 2,700 & 2,304 & 10,745 & 1,600 & 4,229 & 4,084 \\
$1993-94$ & 64,414 & 97,857 & - & 4,200 & 16,000 & 1,720 & 5,392 & 2,515 \\
$1994-95$ & 76,500 & 92,350 & - & 4,000 & 28,930 & 1,800 & 7,000 & 1,100 \\
$1995-96$ & 77,552 & 117,711 & - & 4,400 & 32,630 & 2,500 & 5,774 & 1,018 \\
$1996-97$ & 87,354 & 71,376 & - & 4,800 & 76,300 & 2,000 & 544 & 2,596 \\
$1997-98$ & 88,200 & 78,516 & - & 4,000 & 70,800 & 2,000 & - & 2,620 \\
\hline
\end{tabular}




\begin{tabular}{|r|r|r|r|r|r|r|r|r|r|}
\hline YEAR & \multicolumn{1}{|c|}{ Rabbit } & \multicolumn{1}{c|}{ Fish } & \multicolumn{1}{c|}{ FYM } & $\begin{array}{c}\text { Poult } \\
\text { man }\end{array}$ & $\begin{array}{c}\text { Fodder } \\
\text { grasses }\end{array}$ & \multicolumn{1}{c|}{ Biogas } & $\begin{array}{c}\text { Byprod } \\
\text { others }\end{array}$ & $\begin{array}{c}\text { Gross } \\
\text { return }\end{array}$ & $\begin{array}{c}\text { Net } \\
\text { return }\end{array}$ \\
\hline $1989-90$ & 1,750 & - & 2,250 & 1,000 & 4,800 & 900 & 1,000 & 184,500 & 53,800 \\
$1990-91$ & 900 & - & 3,875 & 1,250 & 5,200 & 1,000 & 4,600 & 188,300 & 58,400 \\
$1991-92$ & 600 & 20,000 & 3,750 & 1,000 & 5,830 & 1,100 & 5,800 & 190,600 & 35,500 \\
$1992-93$ & 980 & 21,100 & 3,750 & 1,875 & 5,940 & 1,300 & 6,400 & 191,900 & 33,500 \\
$1993-94$ & 900 & 20,000 & 5,400 & 2,250 & 6,360 & 1,500 & 6,200 & 231,700 & 55,600 \\
$1994-95$ & 500 & 20,000 & 5,100 & 2,250 & 6,360 & 1,500 & 6,900 & 254,300 & 79,100 \\
$1995-96$ & - & 20,200 & 4,800 & 1,600 & 6,360 & 1,700 & 7,500 & 284,700 & 89,000 \\
$1996-97$ & - & 21,500 & 6,000 & 1,600 & 6,360 & 2,000 & 7,700 & 290,100 & 89,400 \\
$1997-98$ & - & 22,200 & 7,000 & 2,500 & 6,360 & 2,300 & 7,400 & 293,900 & 126,900 \\
\hline
\end{tabular}

* Rounded total

${ }^{* *}$ In case of FYM and Poultry Manure, the imputed value of quantity produced within the system was considered as return

Table 4 Cash Flow Analysis of Coconut Based Mixed Farming Systems

\begin{tabular}{|c|r|r|r|r|r|}
\hline \multirow{2}{*}{ Years } & \multirow{2}{*}{ Total Cost } & \multirow{2}{*}{ Total Return } & \multicolumn{3}{|c|}{ Discounted } \\
\cline { 4 - 6 } & & & Cost & \multicolumn{1}{|c|}{ Return } & Margin \\
\hline $1989-90$ & 134,800 & 184,500 & 118,246 & 161,842 & 43,596 \\
$1990-91$ & 134,000 & 188,300 & 103,109 & 144,891 & 41,782 \\
$1991-92$ & 155,100 & 190,600 & 104,688 & 115,150 & $10,, 462$ \\
$1992-93$ & 158,400 & 191,900 & 93,786 & 113,620 & 19,835 \\
$1993-94$ & 176,100 & 231,700 & 91,461 & 120,338 & 28,877 \\
$1994-95$ & 175,200 & 254,300 & 79,819 & 115,856 & 36,037 \\
$1995-96$ & 195,700 & 284,700 & 78,209 & 113,777 & 35,568 \\
$996-97$ & 200,700 & 290,100 & 70,357 & 101,697 & 31,340 \\
$1997-98$ & 167,000 & 293,900 & 51,354 & 90,377 & 39,023 \\
Total & & & 791,028 & $\mathbf{1 , 0 7 7 , 5 4 7}$ & $\mathbf{2 8 6 , 5 2 0}$ \\
BCR & & & & & $\mathbf{1 . 3 9}$ \\
NPW & & & & & $\mathbf{3 0 6 , 7 7 0}$ \\
IRR & & & & & $\mathbf{2 7 . 5}$ \\
Pay Back & & & & & $\mathbf{0 5}$ \\
\hline
\end{tabular}




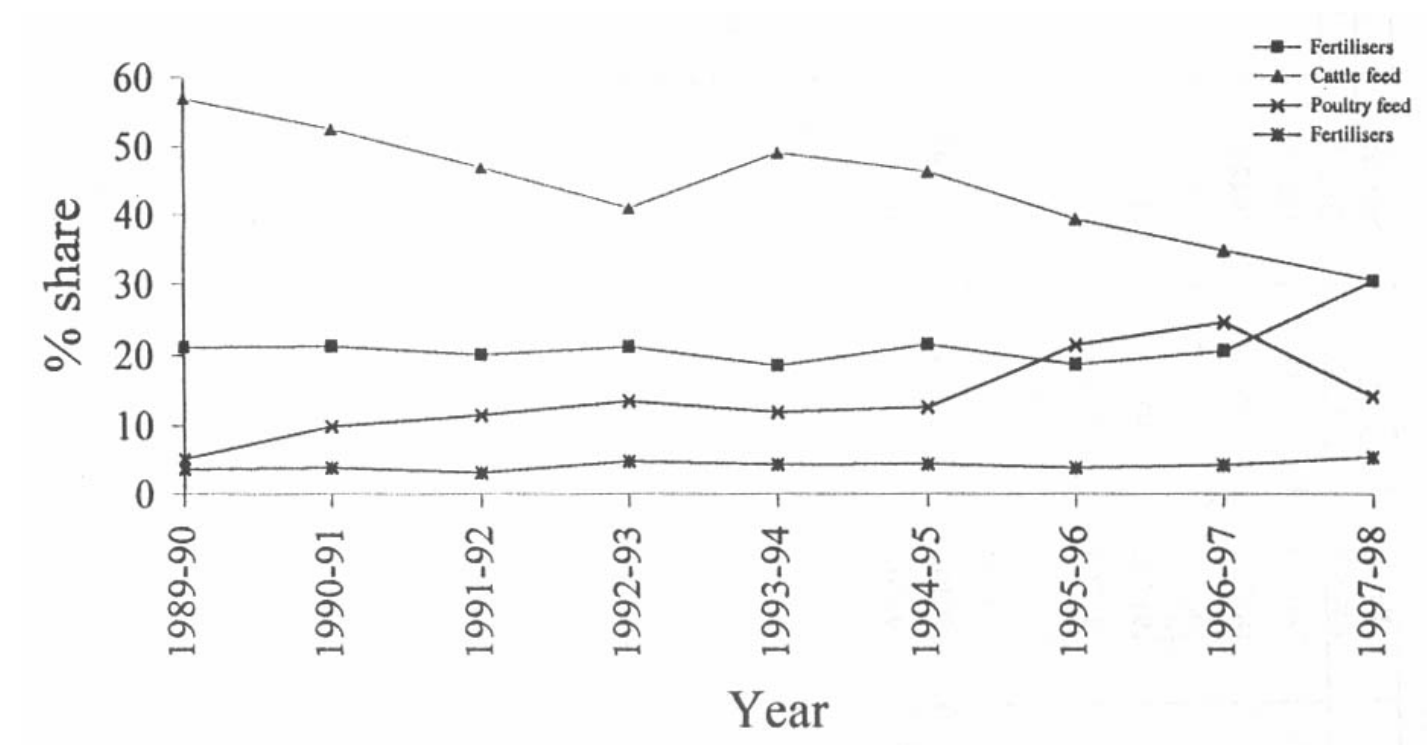

Fig.1: Per cent share of inputs in the variable cost (Rs/ha)

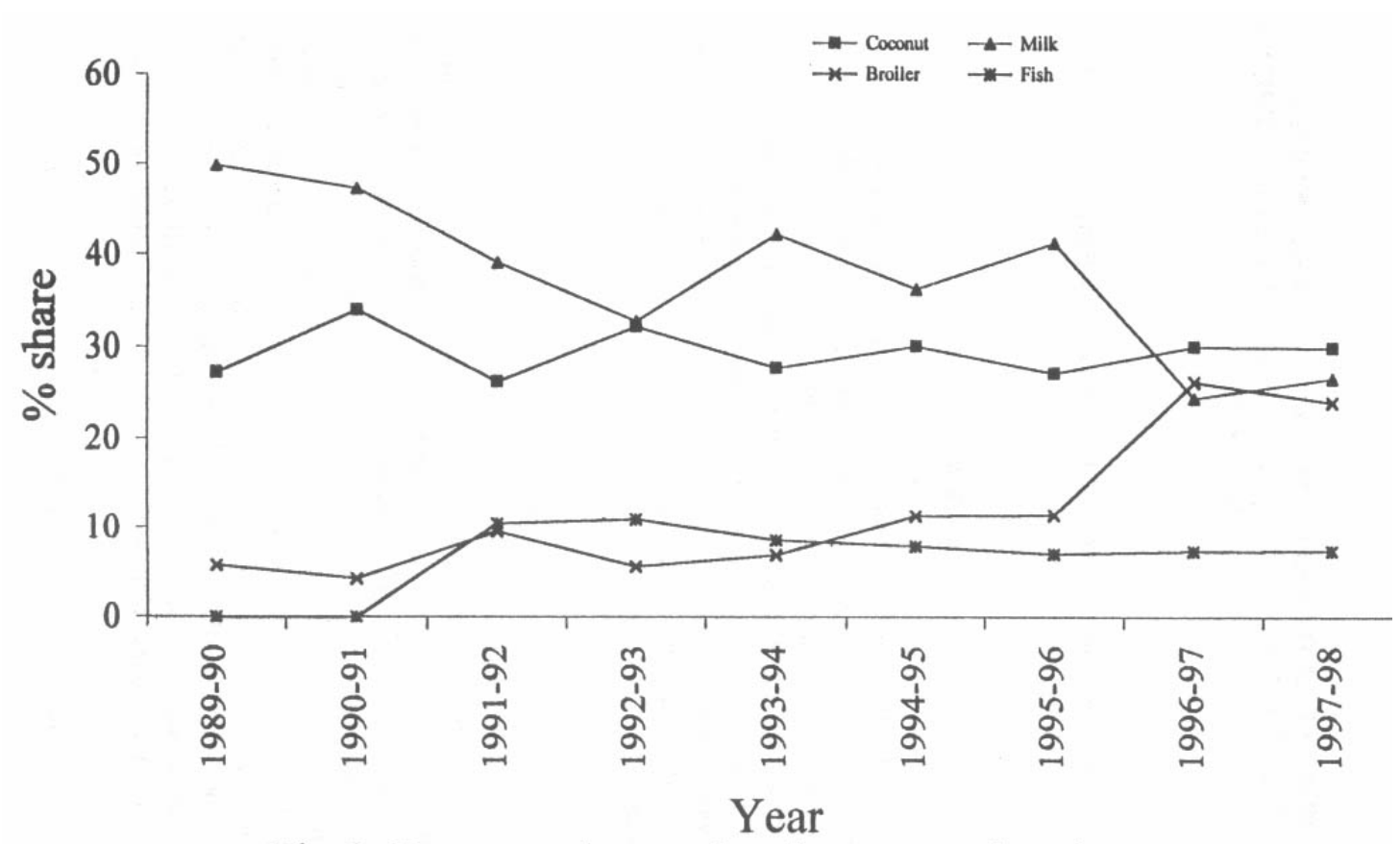

Fig.2: Per cent share of major enterprises in gross returns (Rs/ha) 